\title{
Salmonella Enteritidis detection and immunological cellular response to experimental inoculation in day-old turkeys
}

\section{Detecção e resposta imunológica celular à inoculação experimental de Salmonella Enteritidis em perus de um dia}

\author{
Eliete Souza Santana ${ }^{1 *}$; Thiago Souza Azeredo Bastos²; José Henrique Stringhini; \\ Regiane Nascimento Gagno Porto ${ }^{3}$; Robson Rodrigues Santana ${ }^{4}$; \\ Darling Melany de Carvalho Madrid²; Maria Auxiliadora Andrade ${ }^{3}$
}

\begin{abstract}
The purpose of this research is to clarify aspects of the pathogenesis of Salmonella Enteritidis in experimentally inoculated day-old turkeys. Three treatments were conducted among a total of 120 turkeys; one control group and two treatment groups in which $6 \times 10^{2} \mathrm{CFU} \mathrm{mL}^{-1}$ and $7 \times 10^{5} \mathrm{CFU} \mathrm{mL}^{-1}$, respectively, of Salmonella Enteritidis was inoculated in the crops. Two birds from each treatment were sacrificed and necropsied at 1, 3, 4, 12, 18, and 24 hours, and 3, 4, 38, and 49 days post-inoculation. We re-isolated Salmonella, measured lymphocytes, and conducted immunohistochemical tests. Six hours post-inoculation, Salmonella was found in the investigated organs (yolk sac, cecum, fragments of spleen, and bursa of Fabricius) with conventional bacteriology and immunohistochemistry, and was continuously detected in almost all analyzed organs until turkeys were four-days old. Further, Salmonella was detected after 38 days in cecum, when the concentration $7 \times 10^{5} \mathrm{CFU} \mathrm{mL}^{-1}$ was given. At both inoculation concentrations, the number of lymphocytes was similar; larger quantities were found in the first hour post-inoculation, followed by a gradual reduction, reaching the lowest levels at 24 hours after inoculation. Afterwards, lymphocytes increased discreetly, remaining at the same level until 49 days after inoculation. In conclusion, inoculation concentration influences mitigation, dissemination, elimination, and persistence of this pathogen in turkeys. Lower concentrations promote less invasion as well as lower cell stain and lower lymphocyte count.
\end{abstract}

Key words: Avian salmonellosis. Bacterial isolation. Immunohistochemical. Lymphocytes.

\section{Resumo}

O presente trabalho foi desenvolvido com o objetivo elucidar aspectos que envolvem a patogênese da Salmonella Enteritidis em perus de um dia experimentalmente inoculados. Foram conduzidos três tratamentos, constituídos de 120 perus, sendo um grupo controle e outros dois tratamentos onde se

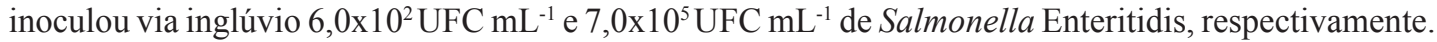
Após a inoculação, duas aves de cada tratamento foram submetidas à eutanásia e ao exame necroscópico para realizar a colheita amostras (saco vitelínico, ceco, fragmentos de baço e bursa de Fabricius) com uma, três, seis, 12, 18 e 24 horas e aos três, quatro, 38 e 49 dias. Foi realizado pesquisa da Salmonella, contagem de linfócitos e imuno-histoquímica. Após seis horas da inoculação, Salmonella foi identificada nos órgãos estudados, tanto pelo teste bacteriológico quanto pelo imunoistoquímico e permaneceu até

\footnotetext{
${ }^{1}$ Profa Dra, Universidade Estadual de Goiás, UEG, Mestrado em Ciências Aplicadas a Produtos para a Saúde, Anápolis, GO, Brasil. E-mail: elietessouza@yahoo.com.br

2 Discentes, Universidade Federal de Goiás, UFG, Goiânia, GO, Brasil. E-mail: tsabvet@gmail.com; melanymadrid@gmail.com

${ }^{3}$ Profs. Drs., Universidade Federal de Goiás, UFG, Goiânia, GO, Brasil. E-mail: jhstring@hotmail.com; rngporto@ufg.br; maa@ ufg.br

${ }^{4}$ Discente, Universidade Federal de Goiás, UFG, Goiânia, GO, Brasil. E-mail: elietessouza@yahoo.com.br

* Author for correspondence
} 
quatro dias de idade em quase todos os órgãos analisados, e até 38 dias no ceco, quando se utilizou $7,0 \times 10^{5} \mathrm{UFC} \mathrm{mL}^{-1}$. Em ambas as concentrações do inóculo, os valores da contagem de linfócitos foram semelhantes, iniciando com maior número de linfócitos na primeira hora pós-inoculação, com redução lenta atingindo menor número às $24 \mathrm{~h}$ pós-inoculação, e, a partir daí, o número de linfócitos aumentou discretamente, se mantendo até os 49 dias pós-inoculação. Conclui-se que a dose infectante influencia a migração, a disseminação, a eliminação e a persistência do patógeno nos perus, pois a menor concentração do inóculo promove menor invasão, assim como menor marcação de células e menor depleção de linfócitos.

Palavras-chave: Imuno-histoquímica. Isolamento bacteriano. Linfócitos. Salmoneloses aviárias.

\section{Introduction}

Food quality and safety are worries of international and national organizations. Turkey meat has attracted increased interest, and with it, there is an increased need to control agents such as Salmonella sp. in production. Because of its complex epidemiology and pathogenicity (TORO et al., 2014), the physiology, genetics, cellular structure, and virulence factors of this genus are constantly studied. This bacteria makes up the most complex group of Enterobacteriaceae, with 2,659 described serovars (ISSENHUTH-JEANJEAN et al., 2014), Enteritidis is considered the most prominent agent in human salmonellosis in many countries (KOTTWITZ et al., 2010).

Salmonella Enteritidis is a public health concern (SULTANA et al., 2014) as it is one of the main causes of gastrointestinal diseases in human beings around the world. It usually arises from contaminated poultry meat and eggs (DESIN et al., 2011), and thus, is a causing of sanitary bans to the trade of poultry and its products (GAMBIRAGI et al., 2003).

In Brazil, between the years 2004 and 2010, Salmonella Enteritidis was the most prevalent serovar, representing $42 \%$ of the total identified serovars in poultry meat (VOSS-RECH et al., 2015). Pires and Hald (2010) detected this serovar in $57.2 \%$ of Salmonella samples from poultry hatcheries, farms, and slaughterhouses. In particular, turkey meat as an infection source has been discussed (EUROPEAN FOOD SAFETY AUTHORITY, 2008).

Hesse et al. (2016) tried to evaluate the immune response of day-old turkeys to attenuated strains of Salmonella, but did not obtain any evidence that these animals developed an immune response.
Other authors have found that there was an increase in proteins (CD4-, CD8 $\alpha$ - e, CD28-positive) after inoculation of virulent strains.

Considering that the physiology and genetic background of each individual may interfere in the defense mechanisms and aggression of microorganisms, the objective of this research is to elucidate the aspects of migration, dissemination, excretion, and cellular immunological response of this pathogen.

\section{Materials and Methods}

This experiment was conducted at the Experimental Nucleus of Avian Diseases, the Bacteriology Laboratory of Preventive Veterinary Medicine Department of Escola de Veterinária e Zootecnia (EVZ) of the Federal University of Goiás (UFG), Goiânia, Goiás, Brazil, and at the Department of Pathological Anatomy and Raising, Health, and Animal Production of Murcia University (UM), Murcia, Murcia province, Spain.

This experiment was approved by the Ethics Committee for Animal Research at UFG, protocol number 103/09. The experiment was performed according to the Ethics Principles in Animal Experimentation adopted by the Brazilian Society of Science in Laboratory Animals (SBCAL).

\section{Experimental design}

For this experiment, 120 day-old British United Turkeys of America (BUTA) were used; they were obtained from commercial hatcheries. The turkeys were distributed in causal blocs, divided into three treatments, with 40 animals in each. The control group (treatment 1 or $\mathrm{T} 1$ ) received $0.1 \mathrm{~mL}$ of sterile 
buffered saline solution $0.85 \%$ orally; treatment 2 (T2) and 3 (T3) animals were inoculated with $0.1 \mathrm{~mL}$ of $0.85 \%$ saline solution at $6 \times 10^{2} \mathrm{CFU} \mathrm{mL} \mathrm{m}^{-1}$ and $7 \mathrm{x}$ $10^{5} \mathrm{CFU} \mathrm{mL} \mathrm{m}^{-1}$, respectively, of Salmonella Enteritidis.

Two birds from each treatment were sacrificed and necropsied at $1,3,6,12,18$, and 24 hours, and 3, 4, 38, and 49 days post-inoculation, totaling 20 animals per treatment. As a safety measure, the same number of birds was kept for replacement in case there was high mortality. These remaining animals were euthanized and cremated at the end of the experiment.

The strains used in this study came from poultry samples given by Andrade et al. (2009). The strain was replicated in agar XLT4 and incubated at $37^{\circ} \mathrm{C}$ for 18 to 24 hours. After that, cells were suspended in buffered saline solution at $0.85 \%$, kept at $4^{\circ} \mathrm{C}$, and concentrations of $7 \times 10^{5} \mathrm{CFU} \mathrm{mL}^{-1}$ and $6 \times 10^{2}$ $\mathrm{CFU} \mathrm{mL} \mathrm{m}^{-1}$ were adjusted with the McFarland scale (FERNÁNDEZ et al., 2001). Plating serial dilution in agar XLT4, incubation at $37^{\circ} \mathrm{C}$, and counting CFU of Salmonella, confirmed each concentration.

All animals were kept at sanitary isolated rooms, which were previously disinfected. Turkeys were kept in galvanized steel cages with four layers, equipped with feeders, drinking fountains, and dropping boxes. Cages were kept warm with $60 \mathrm{~W}$ incandescent lamps for the first 21 days.

\section{Bacterial culture and isolation}

Samplings were macerated and processed as described by the Georgia Poultry Laboratory (1997) and Brasil (2003). Samples of the yolk sac, spleen, bursa of Fabricius, and cecal content of each animal were incubated in Selenite Cystine Broth at $37^{\circ} \mathrm{C}$ for 24 hours. Aliquots of the broth were streaked on selective agar (MacConkey, Hektoen, and XLT4) and incubated at $37^{\circ} \mathrm{C}$ for 24 hours.

Three to five CFUs of each plaque, with phenotypic characteristics of Salmonella, were transferred to tubes containing triple sugar iron agar (TSI), and were incubated at $37^{\circ} \mathrm{C}$ for 24 hours.

TSI tubes with phenotypic and suggestive growth of Salmonella, according to Brasil (2003), were subjected to the urease test, indole production, methyl red, motility, lysine decarboxylase, the malonate test, and Simmons citrate agar test. When biochemical tests were compatible with Salmonella, samples were subjected to serological tests with polyvalent $\mathrm{O}$ antisera; the positive samples were referred to the Oswaldo Cruz Foundation (Fiocruz$\mathrm{RJ}$ ) on nutrient agar for serological confirmation of the isolate.

\section{Lymphocyte counts in lymphoid organs}

Fragments of spleen and bursa of Fabricius were collected for lymphocyte counts. Samples were fixed in 10\% neutral buffered formalin for 24 hours, processed, and included in paraffin. Afterwards, $5.0 \mu \mathrm{m}$ slices were fixed on histological slides and stained with hematoxylin and eosin (HE).

We used planimetry for the lymphocyte counts, in which the number of photographed fields of each sample was determined by the cumulative average, as proposed by Williams (1997). For this, 15 field images were captured from each spleen and bursa of Fabricius fragment of each animal, and lymphocyte count was performed using Image $\mathrm{J}$ software.

A 25 points, a quadrangular reticle was superimposed to the digital histological image, and the only lymphocytes counted were those in the intersections of the visual field. Lymphocytes of the spleen and bursa de Fabricius were sorted depending on depletion, and classified as discreet, moderate, or accentuated.

Initially, we counted control group lymphocytes in the spleen and bursa de Fabricius, calculating average and standard deviation, in order to have a reference and to compare lymphocyte depletion in inoculated animals. We classified them as discreet (when observed depletion was less than 20\%), moderate (when observed depletion was between $20.01 \%$ and $40 \%$ ), and accentuated (when observed depletion was between $40.01 \%$ and $60 \%$ ).

\section{Immunohistochemistry}

We used immunohistochemical analysis in samples of cecum, spleen, and bursa de Fabricius 
from inoculated turkeys at different time points. Tissue samples were collected, fixated in $10 \%$ neutral buffered formalin for 24 hours, processed, and included in paraffin. Afterwards, $5.0 \mu \mathrm{m}$ slices were prepared and placed on histological slides. The slices were diaphanized and hydrated in xylol and ethanol baths, respectively, according to Pickler et al. (2012).

Next, they were subjected to endogenous peroxidase blocking in $1.5 \% \mathrm{H}_{2} \mathrm{O}_{2}$ solution in methanol (195 mL of methanol $+3.0 \mathrm{~mL}$ of $\mathrm{H}_{2} \mathrm{O}_{2}$ ) for 20 minutes. The slides were washed in Tris buffered saline solution (TBS). To block background staining, the slides were incubated with a 1:100 concentration of normal porcine serum, diluted in $2 \%$ bovine serum albumin (BSA), in humid camera at $37^{\circ} \mathrm{C}$, for 20 minutes.

Afterwards, the slides were incubated with the antibody anti-Salmonella ab13634 (Abcam Laboratories, UK), which marks "O" and " $\mathrm{H}$ " antigens, in a humid camera at $37^{\circ} \mathrm{C}$, for one hour. To amplify the reaction, slides were incubated in $1 \%$ secondary antibody biotinylated (anti-rabbit) diluted in BSA at a concentration of 1:250, in humid camera at $37^{\circ} \mathrm{C}$, for 20 minutes. Next, the slides were washed with TBS and incubated with avidinbiotin-peroxidase complex ( $30 \mu \mathrm{L}$ of avidin $+30 \mu \mathrm{L}$ of biotin $+1000 \mu \mathrm{L}$ of TBS) for 20 minutes, and washed again with TBS.

The slides were incubated in diaminobenzidine (DAB), diluted to one drop of DAB in $1.0 \mathrm{~mL}$ of diluent, for five minutes, to reveal the reaction. Slides were washed in water, counter stained with hematoxylin, dehydrated, and mounted under cover slides and synthetic resin. Slides were scored; scoring was determined by the number of marked cells in 10 evaluated fields. After observing the slices, the following scores were given: score $0(-)$ when the percentage of marked cells was up to $1 \%$; score 1 ( + ) when the percentage of marked cells varied from $1-10 \%$; score $2(++)$ when the percentage of marked cells varied from $10-50 \%$; and score $3(+++)$ when the percentage of marked cells varied from $50-90 \%$.

\section{Statistical analysis}

Salmonella Enteritidiscolonization was evaluated by standard bacteriology and immunohistochemical assay to investigate the presence or absence of bacteria; the non-parametric chi-square $\left(\chi^{2}\right)$ test was used to analyze these data. Lymphocyte count data were evaluated by the Kruskal-Wallis test, followed by Dunn's test. Tests were considered statistically significant when $\mathrm{p}<0.05$ (SAMPAIO, 2002).

\section{Results and Discussion}

Results from bacteriological analysis of the yolk sac, spleen, bursa of Fabricius, and cecal content samples from turkeys inoculated with both concentrations of Salmonella Enteritidis are presented in Table 1. Salmonella Enteritidis was not isolated from any animals in the control group.

Table 1. Salmonella Enteritidis isolation at different time points and in different organs of turkeys experimentally inoculated with $6 \times 10^{2}$ and $7 \times 10^{5} \mathrm{CFU} \mathrm{mL}^{-1}$ of Salmonella Enteritidis.

\begin{tabular}{|c|c|c|c|c|}
\hline \multirow{2}{*}{ Age } & \multicolumn{4}{|c|}{$6 \times 10^{2} \mathrm{CFU} \mathrm{mL}^{-1}$ of Salmonella } \\
\hline & . & Cecal Content & Spleen & Bursa of Fabricius \\
\hline 1 hour & $0 \%(0 / 2)$ & $0 \%(0 / 2)$ & $0 \%(0 / 2)$ & $0 \%(0 / 2)$ \\
\hline 3 hours & $0 \%(0 / 2)$ & $0 \%(0 / 2)$ & $0 \%(0 / 2)$ & $0 \%(0 / 2)$ \\
\hline 6 hours & $50 \%(1 / 2)$ & $0 \%(0 / 2)$ & $50 \%(1 / 2)$ & $50 \%(1 / 2)$ \\
\hline 12 hours & $50 \%(1 / 2)$ & $100 \%(2 / 2)$ & $50 \%(1 / 2)$ & $50 \%(1 / 2)$ \\
\hline 18 hours & $100 \%(2 / 2)$ & $100 \%(2 / 2)$ & $100 \%(2 / 2)$ & $100 \%(2 / 2)$ \\
\hline 24 hours & $100 \%(2 / 2)$ & $100 \%(2 / 2)$ & $100 \%(2 / 2)$ & $100 \%(2 / 2)$ \\
\hline 3 days & $100 \%(2 / 2)$ & $50 \%(1 / 2)$ & $100 \%(2 / 2)$ & $100 \%(2 / 2)$ \\
\hline 4 days & $50 \%(1 / 2)$ & $0 \%(0 / 2)$ & $50 \%(1 / 2)$ & $50 \%(1 / 2)$ \\
\hline
\end{tabular}


continuation

\begin{tabular}{|c|c|c|c|c|}
\hline 38 days & - & $0 \%(0 / 2)$ & $0 \%(0 / 2)$ & $0 \%(0 / 2)$ \\
\hline 49 days & - & $0 \%(0 / 2)$ & $0 \%(0 / 2)$ & $0 \%(0 / 2)$ \\
\hline Total & $56 \%(9 / 16)$ & $35 \%(7 / 20)$ & $45 \%(9 / 20)$ & $45 \%(9 / 20)$ \\
\hline \multirow{2}{*}{ Age } & \multicolumn{4}{|c|}{$7 \times 10^{5} \mathrm{CFU} \mathrm{mL}^{-1}$ of Salmonella } \\
\hline & Yolk Sac & Cecal Content & Spleen & Bursa of Fabricius \\
\hline 1 hour & $0 \%(0 / 2)$ & $0 \%(0 / 2)$ & $0 \%(0 / 2)$ & $0 \%(0 / 2)$ \\
\hline 3 hours & $0 \%(0 / 2)$ & $0 \%(0 / 2)$ & $0 \%(0 / 2)$ & $0 \%(0 / 2)$ \\
\hline 6 hours & $50 \%(1 / 2)$ & $50 \%(1 / 2)$ & $50 \%(1 / 2)$ & $50 \%(1 / 2)$ \\
\hline 12 hours & $100 \%(2 / 2)$ & $100 \%(2 / 2)$ & $100 \%(2 / 2)$ & $100 \%(2 / 2)$ \\
\hline 18 hours & $100 \%(2 / 2)$ & $100 \%(2 / 2)$ & $100 \%(2 / 2)$ & $100 \%(2 / 2)$ \\
\hline 24 hours & $100 \%(2 / 2)$ & $100 \%(2 / 2)$ & $100 \%(2 / 2)$ & $100 \%(2 / 2)$ \\
\hline 3 days & $100 \%(2 / 2)$ & $50 \%(2 / 2)$ & $100 \%(2 / 2)$ & $100 \%(2 / 2)$ \\
\hline 4 days & $100 \%(2 / 2)$ & $100 \%(2 / 2)$ & $100 \%(2 / 2)$ & $100 \%(2 / 2)$ \\
\hline 38 days & - & $50 \%(1 / 2)$ & $0 \%(0 / 2)$ & $0 \%(0 / 2)$ \\
\hline 49 days & - & $0 \%(0 / 2)$ & $0 \%(0 / 2)$ & $0 \%(0 / 2)$ \\
\hline Total & $69 \%(11 / 16)$ & $60 \%(12 / 20)$ & $55 \%(11 / 20)$ & $55 \%(11 / 20)$ \\
\hline
\end{tabular}

Inoculated Salmonella was not isolated in any analyzed organs one and three hours postinoculation. These results may be explained by the findings of Flores et al. (2008) and Rocha et al. (2014), who reported that Salmonella adhesion to the epithelium was impaired by natural unspecific defenses of the gastrointestinal tract, or even by immunoglobulins received in the egg which are capable of inhibiting agent development and migration.

From six hours after inoculation to four days-old, samples from birds that received $6 \times 10^{2} \mathrm{CFU} \mathrm{mL}^{-1}$ of Salmonella Enteritidis presented $50 \%$ positivity for Salmonella Enteritidis in the examined organs. However, bacteria was isolated from cecal content from 12 hours to three days after inoculation. Regarding birds that received $7 \times 10^{5} \mathrm{CFU} \mathrm{mL}^{-1}$ of Salmonella Enteritidis, the agent was isolated in all analyzed organs from six hours post-inoculation, and remained detectable in all organs until four days-old, and until 38 days in the cecum. After this period, the bacteria could not be isolated from the organs.

Frequency of isolation varied according to the infecting dose. The yolk sac was positive for Salmonella Enteritidis in 56\% (9/16) and 69\% $(11 / 16)$ of birds, at inoculated concentrations of $6 x$ $10^{2} \mathrm{CFU} \mathrm{mL} \mathrm{m}^{-1}$ and $7 \times 10^{5} \mathrm{CFU} \mathrm{mL}^{-1}$, respectively.
Regarding the 20 birds analyzed for cecal content, $35 \%(7 / 20)$ and $60 \%(12 / 20)$ presented positive for Salmonella Enteritidis, for the lower and higher inoculation concentration, respectively. The pathogen was also detected in 45\% (9/20) and 55\% $(11 / 20)$ of analyzed spleens, as well as in $45 \%(9 / 20)$ and 55\% (11/20) of bursa of Fabricius, with the lower and higher concentrations of Salmonella Enteritidis, respectively. As the age, housing conditions, and management were the same for animals of both treatments, these results suggest that the highest dose, $7 \times 10^{5} \mathrm{CFU} \mathrm{mL}^{-1}$, had higher levels of physical contact with intestinal mucosa, which allowed better invasive capacity and colonization of studied organs. Though there are many factors involved in salmonellosis pathogenesis, it is known that in order to establish infection after oral ingestion, it is necessary to have a physical association between the bacteria and the host epithelium (VAN ASTEN; VAN DIJK, 2005; OLIVEIRA et al., 2013).

However, six hours post-inoculation, the pathogen was identified in all studied organs by conventional bacteriology and immunohistochemistry. Further, greater recuperation occurred in birds that received $7 \times 10^{5} \mathrm{CFU} \mathrm{mL} \mathrm{m}^{-1}$ of Salmonella Enteritidis. These findings may be explained by a combination of events, including Salmonella's time generation of 20 to 35 minutes, its capacity for exponential growth (MALHEIROS et al., 2007), and the 
body temperature of the studied species $\left(41^{\circ} \mathrm{C}\right)$ (WELKER et al., 2008). Another factor that may explain the results is the poor survival capacity of Salmonella in phagocytes after tissue invasion. This gives the bacteria resistance to lysosomal enzyme degradation (OCHOA; RODRÍGUEZ, 2005).

In the current study, it was possible to isolate the bacteria from cecum of turkeys inoculated with $7 \times 10^{5} \mathrm{CFU} \mathrm{mL}^{-1}$ until day 38. These results are similar to those of Cox et al. (2001), who inoculated

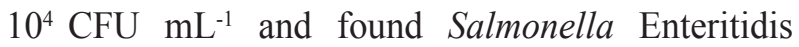
in $46.67 \%$ of cecal content samples in 42 day-old turkeys. In the same study, the authors could not isolate the pathogen after 60 days, regardless of the concentration dose used to inoculate birds. There is a higher susceptibility of intestinal colonization by this bacteria during the early days of a turkey's life; however, this susceptibility diminishes when normal intestinal microbiota continues to develop, up until three to six weeks-old, when this process is completed (NURMI; RANTALA, 1973; BAILEY, 1988).

Another focus of this study was lymphocyte count. Along with microphages, these cells recognize and answer specific foreign antigens, constructing the first line of defense against infection caused by Salmonella Enteritidis (SHEELA et al., 2003).

There was a significant difference in lymphocyte count in the spleen and bursa de Fabricius between the control group and the two other treatment groups (Table 2). Consistent with the observations of Freitas Neto et al. (2007), in the current study, both inoculated groups showed a higher quantity of lymphocytes at the first hour post-inoculation, and a subsequent decrease, reaching the lowest levels 24 hours after inoculation.

Table 2. Lymphocyte count, average percentage, and degree of lymphoid depletion in the spleen and bursa of Fabricius of turkeys inoculated with different concentrations of Salmonella Enteritidis, at different time points post-inoculation.

\begin{tabular}{|c|c|c|c|c|c|c|c|}
\hline TPI- S & Control & $\begin{array}{c}6 \times 10^{2} \\
\text { CFU mL } \mathrm{mL}^{-1}\end{array}$ & $\%$ LD & G & $\begin{array}{c}7 \times 10^{5} \\
\text { CFU mL } \mathrm{mL}^{-1}\end{array}$ & $\%$ LD & G \\
\hline 1 hour & $14.40 \pm 3.01$ & $14.20 \pm 3.21$ & 1.39 & $\mathrm{D}$ & $13.80 \pm 3.60$ & 4.17 & $\mathrm{D}$ \\
\hline 3 hours & $15.10 \pm 3.22$ & $13.10 \pm 2.90$ & 13.25 & $\mathrm{D}$ & $12.10 \pm 3.99$ & 19.87 & $\mathrm{D}$ \\
\hline 6 hours & $15.9 \pm 3.32 \mathrm{a}$ & $13.20 \pm 2.31 \mathrm{ab}$ & 16.98 & $\mathrm{D}$ & $11.20 \pm 5.00 \mathrm{~b}$ & 29.56 & M \\
\hline 12 hours & $16.20 \pm 3.75 \mathrm{a}$ & $14.90 \pm 1.75 \mathrm{a}$ & 8.02 & $\mathrm{D}$ & $10.60 \pm 3.85 b$ & 34.57 & $\mathrm{D}$ \\
\hline 18 hours & $16.90 \pm 3.84 a$ & $13.20 \pm 4.90 \mathrm{ab}$ & 21.89 & M & $9.80 \pm 4.31 b$ & 42.01 & A \\
\hline 24 hours & $16.80 \pm 5.25 a$ & $9.40 \pm 4.40 b$ & 44.05 & A & $7.10 \pm 2.87 \mathrm{c}$ & 57.74 & A \\
\hline 3 days & $15.20 \pm 3.61 \mathrm{a}$ & $13.10 \pm 3.12 \mathrm{a}$ & 13.82 & $\mathrm{D}$ & $9.00 \pm 2.46 b$ & 40.79 & A \\
\hline 4 days & $14.40 \pm 3.15 \mathrm{a}$ & $11.40 \pm 3.29 \mathrm{ab}$ & 20.83 & M & $9.20 \pm 4.88 \mathrm{~b}$ & 36.11 & M \\
\hline 38 days & $14.20 \pm 3.59 a$ & $11.60 \pm 2 ., 82 b$ & 18.31 & $\mathrm{D}$ & $9.70 \pm 5.54 b$ & 31.69 & M \\
\hline 49 days & $13.70 \pm 3.80$ & $11.00 \pm 4.10$ & 19.71 & $\mathrm{D}$ & $10.60 \pm 8.24$ & 22.63 & M \\
\hline TPI- BF & Control & $\begin{array}{c}6 \times 10^{2} \\
\text { UFC } \mathrm{mL}^{-1}\end{array}$ & $\%$ LD & G & $\begin{array}{c}7 \times 1^{5} \\
\text { CFU mL } \mathrm{mL}^{-1} \\
\end{array}$ & $\%$ LD & $\mathbf{G}$ \\
\hline 1 hour & $17.40 \pm 3.71$ & $15.10 \pm 3.09$ & 13.22 & $\mathrm{D}$ & $15.10 \pm 3.70$ & 13.22 & $\mathrm{D}$ \\
\hline 3 hours & $16.70 \pm 4.41 \mathrm{a}$ & $14.30 \pm 5.22 \mathrm{ab}$ & 14.37 & $\mathrm{D}$ & $12.60 \pm 5.13 b$ & 24.55 & M \\
\hline 6 hours & $17.20 \pm 4.53 a$ & $13.80 \pm 2.45 \mathrm{ab}$ & 19.77 & $\mathrm{D}$ & $11.70 \pm 8.11 b$ & 31.98 & M \\
\hline 12 hours & $17.60 \pm 2.99 a$ & $12.00 \pm 4.49 b$ & 31.82 & M & $10.20 \pm 3.57 b$ & 42.05 & A \\
\hline 18 hours & $17.50 \pm 3.48 \mathrm{a}$ & $11.60 \pm 4.62 b$ & 33.71 & M & $9.00 \pm 4.72 b$ & 48.57 & A \\
\hline 24 hours & $19.00 \pm 4.62 \mathrm{a}$ & $9.00 \pm 3.59 b$ & 52.63 & $\mathrm{~A}$ & $8.00 \pm 4.39 b$ & 57.89 & A \\
\hline 3 days & $17.70 \pm 3.65 \mathrm{a}$ & $10.40 \pm 4.45 b$ & 41.24 & A & $9.80 \pm 5.28 b$ & 44.63 & A \\
\hline 4 days & $17.50 \pm 4.80 \mathrm{a}$ & $14.20 \pm 4.89 \mathrm{ab}$ & 18.86 & $\mathrm{D}$ & $10.60 \pm 3.26 b$ & 39.43 & M \\
\hline 38 days & $16.10 \pm 2.69 \mathrm{a}$ & $12.00 \pm 5.09 b$ & 25.47 & M & $10.40 \pm 4.48 b$ & 35.40 & M \\
\hline 49 days & $14.90 \pm 5.37 \mathrm{a}$ & $10.40 \pm 4.40 b$ & 30.20 & M & $9.90 \pm 3.65 b$ & 33.56 & M \\
\hline
\end{tabular}

$\mathrm{a}, \mathrm{b}$ - Averages followed by letters in the same line are significantly different with the Kruskal-Wallis test at 5\%. TPI - Time postinoculation. LD - Lymphoid depletion. S - Spleen. BF - Bursa of Fabricius. G - Degree of lymphoid depletion; D - Discreet; M - Moderate; A - Accentuated. 
However, after 24 hours, the lymphocyte count increased slightly, and remained stable until 49 days after inoculation. According to Hassan and Curtiss (1994), this transitory increase of lymphocytes in lymphoid organs may benefit the development of carrier birds. Even so, as previously reported, the pathogen was not identified in organs or cecal content after 38 days. According to Freitas Neto et al. (2007), the immune response is essential in order to limit Salmonella intestinal invasion and its dissemination to other lymphoid organs and the liver.

Lymphoid depletion observed in the spleen varied from 1.39 to $44.05 \%$, and from 4.17 to $57.74 \%$, respectively, for the lower and higher Salmonella concentrations. The depletion was predominantly discreet and moderate. In the bursa of Fabricius, lymphoid depletion varied from 13.22 to $52.63 \%$, and from 13.22 to $57.89 \%$, with the lower and higher Salmonella concentrations, respectively.
Generally, the higher Salmonella concentration caused accentuated lymphoid depletion in the spleen and bursa of Fabricius, at almost all observed ages.

It is possible that lymphoid depletion with both the lower and higher Salmonella concentrations occurred because of cell migration to the site of injury, cell recruitment to places of bacterial invasion, or by commitment of lymphoid organs responsible for production and storage of these cells. In this scenario, the infected organism cannot efficiently replenish new lymphocytes to combat infection.

The results of the immunohistochemistry to antibody anti-Salmonella ab13634 in fragments of cecum, spleen, and bursa of Fabricius among turkeys challenged with different concentrations of Salmonella Enteritidis, are presented on Table 3. As was observed with conventional bacteriology, there were no positive immunohistochemistry reactions in the organs of the control group animals.

Table 3. Scores for immunohistochemistry marks in organs of turkeys inoculated with different concentrations of Salmonella Enteritidis.

\begin{tabular}{|c|c|c|c|c|c|c|c|c|c|c|}
\hline \multirow{2}{*}{$\begin{array}{l}\text { Organs/Time Post- } \\
\text { inoculation }\end{array}$} & \multicolumn{10}{|c|}{ Inoculum with $6 \times 10^{2} \mathrm{CFU} \mathrm{mL}^{-1}$} \\
\hline & $1 \mathrm{~h}$ & $3 \mathrm{~h}$ & $6 \mathrm{~h}$ & $12 \mathrm{~h}$ & $18 \mathrm{~h}$ & $24 \mathrm{~h}$ & $3 \mathrm{~d}$ & $4 d$ & $38 \mathrm{~d}$ & $49 d$ \\
\hline Cecum & - & - & - & + & ++ & ++ & ++ & + & - & - \\
\hline Spleen & - & - & + & + & ++ & + & + & + & - & - \\
\hline Bursa of Fabricius & - & - & + & + & ++ & ++ & + & + & - & - \\
\hline \multirow{2}{*}{$\begin{array}{l}\text { Organs/Time Post- } \\
\text { inoculation }\end{array}$} & \multicolumn{10}{|c|}{ Inoculum with $7 \times 10^{5} \mathrm{CFU} \mathrm{mL}^{-1}$} \\
\hline & $1 \mathrm{~h}$ & $3 \mathbf{h}$ & $6 \mathrm{~h}$ & $12 \mathrm{~h}$ & $18 \mathrm{~h}$ & $24 \mathrm{~h}$ & 3 d & $4 d$ & $38 \mathrm{~d}$ & $49 d$ \\
\hline Cecum & - & - & + & + & ++ & ++ & ++ & ++ & - & - \\
\hline Spleen & - & - & + & ++ & ++ & +++ & ++ & + & - & - \\
\hline Bursa de Fabricius & - & - & - & + & ++ & ++ & + & + & - & - \\
\hline
\end{tabular}

$(-)$ absence of marking; $(+)$ discreet number of cells; $(++)$ moderate number of cells; $(+++)$ high number of cells.

Targeted cells were observed only between six hours to four days post-inoculation. Desmidt et al. (1998) observed similar findings in the cecal epithelial surface of poultry six hours after inoculation. This reinforces the notion that establishment of infection is related to the time of pathogen inoculation.

In birds who received the lower Salmonella concentration, marking variation was discreet and moderate, and markings were initially detected in the spleen and the bursa of Fabricius. There was an increase in marked cells only after 18 hours post-inoculation, and this remained stable until the third day in the cecum. However, in the T3 group, marking began in the cecum and the spleen, and a high score was observed in the spleen at 24 hours. There was an increase of marked cells 12 hours after inoculation, and this remained stable in the 
cecum until the fourth day. Figures 1 and 2 show the immunohistochemistry for Salmonella Enteritidis in different tissues and at different time points postinoculation, for both treatment groups.

These data suggest that higher concentration doses inoculated in turkeys lead to longer periods that these birds may be carriers. Similar observations were made by Asheag et al. (2003) when they inoculated two doses of Salmonella Enteritidis ( $2 \mathrm{x}$ $10^{2} \mathrm{CFU} \mathrm{mL} \mathrm{mL}^{-1}$ and $2 \times 10^{8} \mathrm{CFU} \mathrm{mL}^{-1}$ ) in laying hens. These authors reported that animals that received the lower quantity of Salmonella presented discreet cecal superficial epithelium marking between 10 hours and seven days after inoculation, while animals that received the higher quantity presented Salmonella adhesion to cecal superficial epithelium from six hours to 14 days after inoculation, persisting up to three weeks in connective tissues. According to these authors, this suggests that Salmonella Enteritidis' capacity for adhesion and colonization of the intestinal tract is dose dependent, as was observed in the current study. Regarding the affected organs, Deng et al. (2008) also observed high levels of Salmonella Enteritidis in different organs of ducks.

Figure 1. Photomicrographs of bursa of Fabricius and cecum of turkeys challenged with $6 \times 10^{2} \mathrm{CFU} \mathrm{mL}^{-1}$ of Salmonella Enteritidis. A) Bursa, $12 \mathrm{~h}$ post-inoculation, presenting with score 1 to antibody anti-Salmonella ab13634. IHQ, 630x. B) Cecum, 4 days after inoculation, presenting with score 2 to antibody anti-Salmonella ab13634. IHQ, 400x. Source: Authors.
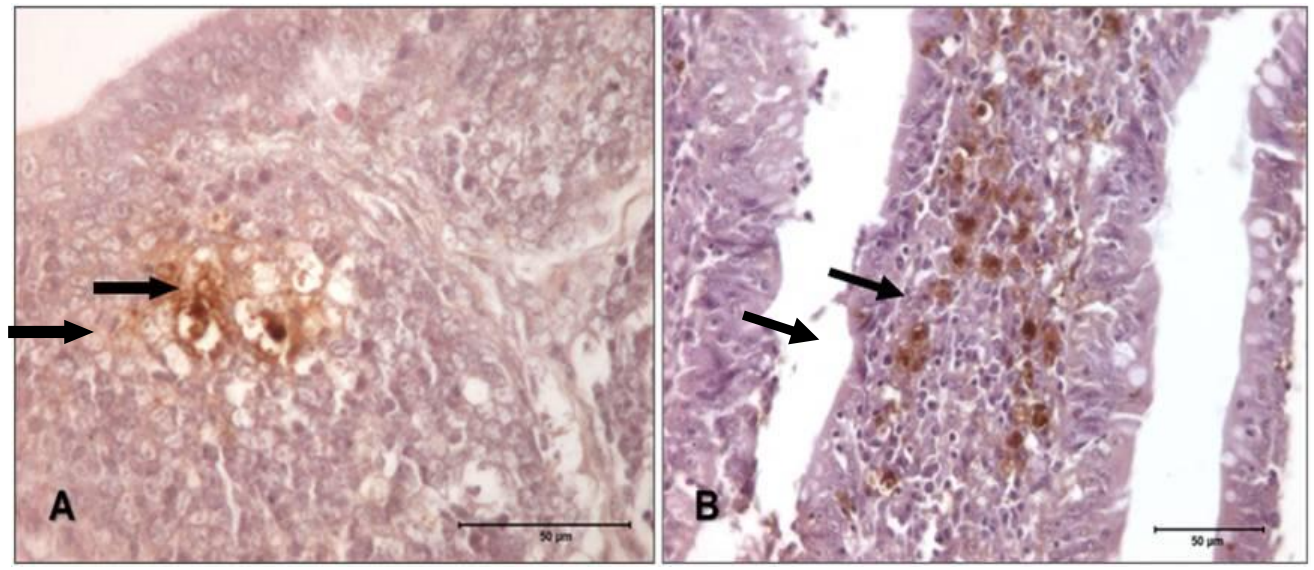

Figure 2. Photomicrography of spleen and bursa of Fabricius of turkeys challenged with $7 \times 10^{5} \mathrm{CFU} \mathrm{mL}^{-1}$ of Salmonella Enteritidis. A) Spleen, $18 \mathrm{~h}$ post-inoculation, presenting with score 2 to antibody anti-Salmonella ab13634. IHQ, 630x. B) Bursa of Fabricius, $12 \mathrm{~h}$ post-inoculation, presenting with score 1 to antibody anti-Salmonella ab13634. IHQ, 400x. Source: Authors.
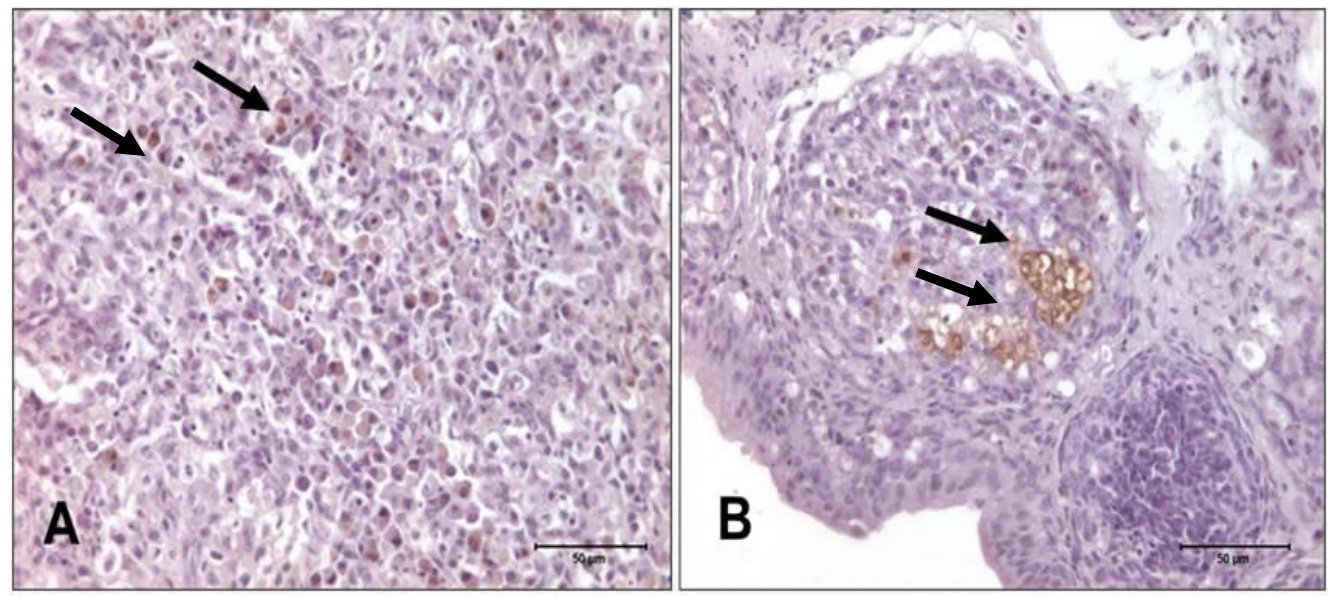


\section{Conclusion}

In this study, bacteriological, immunohistochemical, and lymphoid count results showed that the severity of infection is dose dependent; the infectious dose influences migration to organs, dissemination, and cell response. Further, regardless of inoculated concentration, turkeys were capable of quelling the infection and eliminating the bacteria until 49 days of age, according to the period studied in this research.

\section{References}

ANDRADE, M. A.; MESQUITA, A. J.; STRINGHINI, J. H.; BRITO, L. A. B.; CHAVES, L. S.; MATTOS, M. S. Aspectos clínicos e anatomo histopatológicos de pintos de corte oriundos de ovos inoculados experimentalmente com Salmonella Enteritidis fagotipo 4. Ciência Animal Brasileira, Goiânia, v. 10, n. 3, p. 909-917, 2009.

ASHEAG, A. A.; LEVKUT, M.; REVAJOVÁ, V.; SEVCIKOVA, Z.; KOLODZIEYSKI, L.; PISTIL, J.; PILIPCINEC, E. Spreading of Salmonella Enteritidis in the cecum of chickens. Folia Microbiologica, Praha, v. 48, n. 2, p. 277-279, 2003.

BAILEY, J. S. Integrated colonization control of Salmonella in poultry. Poultry Science, Champaign, v. 67, n. 6, p. 928-932, 1988.

BRASIL. Ministério da Agricultura e do Abastecimento. Secretaria Nacional da Defesa Agropecuária. Departamento Nacional de Defesa Animal. Coordenação Geral de Laboratório Animal. Métodos de análises microbiológicas para alimentos. Brasília: MAPA, 2003. $226 \mathrm{p}$.

COX, N. A.; BAILEY, J. S.; STERN, N. J. Effectiveness of an undefined mucosal competitive exclusion treatment to control Salmonella in turkeys during brooding. Journal of Applied Poultry Research, Champaign, v. 10, n. 2, p. 319-322, 2001.

DENG, S. X.; CHENG, A. C.; WANG, M. S.; YAN, B.; YIN, N. C.; CAO, S. Y.; ZHANG, Z. H.; CAO, P. The pathogenesis of Salmonella Enteritidis in experimentally infected ducks: a quantitative time-course study using TaqMan polymerase chain reaction. Poultry Science, Champaign, v. 87, n. 9, p. 1768-1772, 2008.

DESIN, T. S.; WISNER, A. L. S.; LAM, P. S.; BERBEROV, E.; MICKAEL, C. S.; POTTER, A. A.; KOSTER, W. Evaluation of Salmonella enterica serovar Enteritidis pathogenicity island-1 proteins as vaccine candidates against $S$. Enteritidis challenge in chickens. Veterinary Microbiology, Miyazaki, v. 148, n. 2, p. 298307, 2011.

DESMIDT, M.; DUCATELLE, R.; MAST, J.; GODDEERIS, B. M.; KASPERS, B.; HALSEBROUCK, F. Role of the humoral immune system in Salmonella Enteritidis phage type four infection in chickens. Veterinary Immunology and Immunopathology, New York, v. 63, n. 4, p. 355-367, 1998.

EUROPEAN FOOD SAFETY AUTHORITY - EFSA. Report of the task force on zoonoses data collection on the analysis of the baseline survey on the prevalence of Salmonella in turkey flocks, Part B. EFSA Journal, Parma, v. 198, p. 1-124, 2008.

FERNÁNDEZ, A.; LARA, C.; LOSTE, A.; CALVO, S.; MARCA, M. C. Control of Salmonella Enteritidis phage type 4 experimental infection by fosfomycin in newly hatched chicks. Comparative Immunology, Microbiology \& Infections Disease, Oxford, v. 24, n. 4, p. 207-216, 2001.

FLORES, G. R.; CASAS, F. C.; LÓPEZ, J. A. Q.; PELÃEZ, C. C.; BRAVO, O. U. Patogenia de Salmonella Enteritidis FT 13a y Salmonella Enteritidis biovarIssatschenko en pollos de engorda. Veterinária México, Cidade do México, v. 39, n. 2, p. 145-160, 2008.

FREITAS NETO, O. C.; ARROYAVE, W. H.; ALESSI, A. C.; FAGLIARI, J. J.; BERCHIERI JÚNIOR, A. Infection of commercial laying hens with Salmonella Gallinarum: clinical, anatomopathological and haematological studies. Brazilian Journal of Poultry Science, Campinas, v. 9, n. 2, p. 133-141, 2007.

GAMBIRAGI, A. P. O. M.; SALLES, R. P. R.; AGUIAR FILHO, J. L.; OLIVEIRA, W. F.; MACIEL, W. C.; ROMÃO, J. M.; TEIXEIRA, R. S. C. Salmonella sp em frangos de corte de um dia de idade na região metropolitana de Fortaleza-CE. Acta Scientiae Veterinariae, Porto Alegre, v. 31, n. 3, p. 149-153, 2003.

GEORGIA POULTRY LABORATORY. Monitoring and detection of Salmonella in poultry and poultry environments. Oakwood: Georgia Poultry Laboratory, 1997. $293 \mathrm{p}$.

HASSAN, J. O.; CURTISS, R. I. I. I. Development and evaluation of oral vaccination program using live avirulent Salmonella Typhimurium to protect vaccinated chickens against challenge with homologous and heterologous Salmonella serotypes. Infection and Immunity, Washington, v. 62, n. 12, p. 5519-5527, 1994.

HESSE, M.; STAMM, A.; WEBER, R.; GLÜNDER, G.; BERNDT, A. Immune response of turkey poults exposed at 1 day of age to either attenuated or wild Salmonella 
strains. Veterinary Immunology and Immunopathology, New York, v. 174, p. 1-10, 2016.

ISSENHUTH-JEANJEAN, S.; ROGGENTIN, P.; MIKOLEIT, M.; GUIBOURDENCHE, M.; De PINNA, E.; NAIR, S.; WEILL, F. X. Supplement 2008-2010 (no. 48) to the White-Kauffmann-Le Minor scheme. Research in Microbiology, Paris, v. 165, n. 7, p. 526-530, 2014.

KOTTWITZ, L. B. M.; OLIVEIRA, T. C. R. M.; ALCOCER, I.; FARAH, S. M. S. S.; ABRAHÃO, W. S. M.; RODRIGUES, D. P. Avaliação epidemiológica de surtos de salmonelose ocorridos no período de 1999 a 2008 no Estado do Paraná, Brasil. Acta Scientiarum. Health Sciences, Maringá, v. 32, n. 1, p. 9-15, 2010.

MALHEIROS, P. S.; PAULA, C. M. D. de; TONDO, E. C. Cinética de crescimento de Salmonella Enteritidis envolvida em surtos alimentares no RS: uma comparação com linhagens de outros sorovares. Ciência e Tecnologia de Alimentos, Campinas, v. 27, n. 4, p. 751-755, 2007.

NURMI, E.; RANTALA, M. New aspects of Salmonella infection in broiler production. Nature, London, v. 241, n. 5386 , p. $210-211,1973$.

OCHOA, I. M. F.; RODRÍGUEZ, A. V. Mecanismos moleculares de patogenicidad de Salmonella sp. Revista Latinoamericana de Microbiología, Cidade do México, v. 47, n. 1-2, p. 25-42, 2005.

OLIVEIRA, A. P.; SOLA, M. S.; FEISTEL, J. C.; MOREIRA, N. M.; OLIVEIRA, J. J. Salmonella enterica: genes de virulência e ilhas de patogenicidade. Enciclospédia Biosfera, Goiânia, v. 9, n. 16, p. 19471972, 2013.

PICKLER, L.; HAYASHII, R. M.; LOURENÇO, M. C.; MIGLINO, L. B.; CARON, L. F.; BEIRÃO, B. C. B.; SILVA, A. V. F.; SANTIN, E. Avaliação microbiológica, histológica e imunológica de frangos de corte desafiados com Salmonella Enteritidis e Minnesota e tratados com ácidos orgânicos. Pesquisa Veterinária Brasileira, Rio de Janeiro, v. 32, n. 1, p. 27-36, 2012.

PIRES, S. M.; HALD, T. Assessing the differences in public health impact of Salmonella subtypes using a Bayesian microbial subtyping approach for source attribution. Foodborne Pathogens and Disease, Spring, v. 7, n. 2, p. 143-151, 2010.
ROCHA, D. C. C.; MARINHO, A. N. R.; REIS, M. S. O.; BORGES, I. R.; RAMOS, F. L. P.; LOUREIRO, E. C. B. Perfil epidemiológico e caracterização molecular de Salmonella Typhi isoladas no Estado do Pará, Brasil. Revista Pan-Amazônica Saúde, Ananindeua, v. 5, n. 4, p. 53-62, 2014.

SAMPAIO, I. B. M. Estatística aplicada à experimentação animal. Belo Horizonte: Fundação de Ensino e Pesquisa em Medicina Veterinária e Zootecnia, 2002. 221 p.

SHEELA, R. R.; BABU, U.; MU, J.; ELANKUMARAN, S.; BAUTISTA, D. A.; RAYBOURNE, R. B.; HECKERT, R. A.; SONG, W. Immune responses against Salmonella enterica serovar Enteritidis infection in virally immunosuppressed chickens. Clinical and Diagnostic Laboratory Immunology, Washington, v. 10, n. 4, p. 670679, 2003.

SULTANA, M.; BILKIS, R.; DIBA, F.; HOSSAIN, M. Predominance of multidrug resistant zoonotic Salmonella Enteritidis genotypes in poultry of Bangladesh. Journal of Poultry Science, Honduras, v. 51, n. 4, p. 524-534, 2014.

TORO, M.; SERAL, C.; ROJO-BEZARES, B.; TORRES, C.; JAVIER CASTILLO, F.; SÁENZ, Y. Resistencia a antibióticos y factores de virulencia en aislados clínicos de Salmonella entérica. Enfermedades Infecciosas y Microbiología Clínica, Barcelona, v. 32, n. 1, p. 4-10, 2014.

VAN ASTEN, A. J. A. M.; VAN DIJK, J. E. Distribution of classic virulence factors among Salmonella spp. Fems Immunology and Medical Microbiology, Oxford, v. 44, n. 3, p. 251-259, 2005.

VOSS-RECH, D.; VAZ, C. S. L.; ALVES, L.; COLDEBELlA, A.; LEÂO, J. A.; RODRIGUES, D. P.; BACK, A. A temporal study of Salmonella enterica serotypes from broiler farms in Brazil. Poultry Science, Champaign, v. 94, n. 3, p. 433-441, 2015.

WELKER, J. S.; ROSA, A. P.; MOURA, D. J.; MACHADO, L. P.; CATELAN, F.; UTTPATEL, R. Temperatura corporal de frangos de corte em diferentes sistemas de climatização. Revista Brasileira de Zootecnia, Viçosa, MG, v. 37, n. 8, p. 1463-1467, 2008.

WILLIAMS, M. A. Quantitative methods in biology, In: GLAUBERT, A. M. Practical methods in electron microscopy. Amsterdam: Elsevier North-Holland Biomedical Press, 1977. p. 29-38. v. 6. 